\title{
1 Inversion breakpoints and the evolution of supergenes
}

2 Romain Villoutreix ${ }^{1}$, Diego Ayala ${ }^{2}$, Mathieu Joron ${ }^{1}$, Zachariah Gompert ${ }^{3}$, Jeffrey L. Feder ${ }^{4}$,

3 Patrik Nosil ${ }^{1}$.

4 Molecular Ecology 30 (12): 2738-2755. https://doi.org/10.1111/mec.15907

$6 \quad{ }^{1}$ CEFE, CNRS, Univ. Montpellier. 1919 Route de Mende. 34293 Montpellier. France

72 UMR MIVEGEC, IRD, CNRS, Univ. Montpellier, 911 avenue Agropolis, BP 64501, 34394

8 Montpellier, France.

$9{ }^{3}$ Department of Biology, Utah State University, Utah 84322, USA

$10{ }^{4}$ Department of Biological Sciences, University of Notre Dame, Notre Dame, Indiana 46556,

11 USA

13 Abstract

15 The coexistence of discrete morphs that differ in multiple traits is common within natural 16 populations of many taxa. Such morphs are often associated with chromosomal inversions,

17 presumably because the recombination suppressing effects of inversions helps maintain 18 adaptive combinations for traits that are controlled by different genes (supergene 19 hypothesis). However, inversions can also harbor adaptive mutations at their breakpoints, 20 leading to rise in inversion frequency in addition to (or independent from) a role for 21 recombination suppression (breakpoint-mutation hypothesis). In this review, we first 
22 describe the myriad of ways that breakpoints can create mutations. We then critically

23 examine the evidence for both hypotheses in examples of putative supergenes. Despite

24 decades of focused study, we find that evidence that inversions spread due to

25 recombination suppression, as proposed by the supergene hypothesis, is often indirect.

26 Breakpoints may harbor mutations that are adaptive in many cases, but again the evidence

27 is indirect and characterization of inversion breakpoints at the sequence level is incomplete

28 in most systems. Direct tests of the role of suppressed recombination and breakpoint

29 mutation in inversion evolution are needed. Finally, we emphasize how the two hypotheses

30 can act in conjunction, with implications for understanding the dynamics of supergene

31 evolution. We conclude that breakpoint characterization could be essential for

32 understanding the origin of complex, discrete phenotypic forms in nature.

34 Keywords: chromosomal inversion, linkage, mutation, recombination, genome evolution. 
37 The origin and maintenance of discrete morphs within natural populations has long 38 fascinated evolutionary biologists (Darwin, 1862; Fisher, 1930; Ford, 1971). Because of the

39 discrete nature of the phenotypic differences observed, this variation was often assumed to 40 have a genetic origin, making its study of primary interest for early geneticists (see Chapter 416 of (Ford, 1971) for a good overview of genetic programs of the time). Moreover, the diverse nature of the traits that usually differ between these morphs (color, morphology, sexual-compatibility, etc.), led to the hypothesis that the genetic basis of this discrete variation is a functional unit containing multiple loci, coined as a "Super-gene" (spelled supergene hereafter; see glossary) by Darlington and Mather in 1949 (Fisher, 1930; Ford, 1965; Mather, 1955). Fisher anticipated that genetic linkage between multiple selected loci could evolve under natural selection (Fisher, 1930) and Ford later suggested that linkage could be increased via translocation or chromosomal inversions (Ford, 1971). Chromosomal inversions can indeed strongly reduce recombination between the genomic segments they contain, a property leading to their discovery in 1921 by Sturtevant (Sturtevant, 1921).

Examples of discrete morphs associated with chromosomal inversions (i.e., candidate supergenes; see glossary) are accumulating rapidly, leading to peaked interest in supergene and inversion evolution. There are currently two core hypotheses for how and why supergenes and inversions evolve. First and perhaps more accepted, inversions can be selected for their capacity to impede recombination between sets of epistatic or locally adapted genes (i.e., supergene hypothesis; see glossary) (Kirkpatrick, 2010; Kirkpatrick \& Barton, 2006). This hypothesis predicts that loci underlying trait variation will generally be distributed across the inversion. Second, inversions can create adaptive mutations at their 
breakpoints (i.e. breakpoint-mutation hypothesis; see glossary; Fig. 1A) (Dobzhansky, 1947, 1970; Kirkpatrick, 2010), leading to their rise in frequency via selection on breakpoint variants. This hypothesis predicts that adaptive mutations will be localized at breakpoints, rather than more widely distributed throughout the inversion. Notably, a breakpoint mutation can, in principle, be pleiotropic and affect multiple traits. Therefore, even when multiple traits are associated with an inversion, a role for recombination suppression needs to be demonstrated rather than assumed. As we discuss in more detail below, these hypotheses are not mutually exclusive and might combine to drive supergene evolution (i.e. breakpoint-linkage hypothesis; see glossary; Fig. 1A). Indeed, theory implies that for new inversions to establish under the supergene hypotheses, they must capture all segregating variants at selected loci in a favorable combination (Kirkpatrick \& Barton, 2006). Alternatively, an inversion with an adaptive breakpoint mutation may be able to initially rise in frequency and persist for a sufficient amount of time to allow for the sorting out of any initially captured maladapted alleles (e.g., via gene conversion and double-recombination events).

Distinguishing among these hypotheses (Fig. 1A) is important as it will help answer the following major questions concerning adaptation and genome rearrangement (Fig 1.B). Do divergent selected variants evolve first and subsequently become locked together via suppressed recombination within an inversion (Kirkpatrick \& Barton, 2006) ? Do inversions establish first because of an adaptive breakpoint mutation such that they are only subsequently turned into supergenes by the emergence of new variants within them

80 (Navarro \& Barton, 2003) ? Or, in contrast, pre-existing divergently selected variants and adaptive breakpoint mutations tend to coincide when supergenes form via the emergence 
82 of an inversion? The answers to these questions are important because they determine the

83 roles for mutation, pre-standing genetic variation and recombination in adaptation.

84 In this review, we critically examine the evidence for the three hypotheses mentioned previously regarding inversion evolution. We begin with a discussion of the mechanisms by which breakpoints can create adaptive mutations, as this is often a less appreciated facet of inversions than is recombination suppression. We then empirically review well-known cases of candidate supergenes (Box 2 - Fig. 1). Our collective findings lead us to propose that characterization of breakpoints at the sequence level could be crucial for understanding the evolutionary dynamics of supergenes. Specifically, the most common molecular mechanism generating inversions also generates duplications at both end of the inverted segment (Ranz et al., 2007). This offers a unique opportunity to date inversions, independently from their content, and test if they emerged before or after the divergently selected loci they may contain. Thus, breakpoint characterization could be essential for understanding the origin and maintenance of complex, discrete phenotypic forms in nature.

\section{Molecular mechanisms by which inversion breakpoints can create adaptive mutations}

97 The idea that inversions might be selected because of an adaptive mutation at one of their

98 breakpoints is not new (Dobzhansky, 1947). However, this hypothesis is yet to receive highly

99 focused study in supergene evolution, despite known molecular mechanisms that are likely

100 to create a breakpoint mutation whenever inversions form. Two main processes can

101 generate chromosomal inversions, ectopic recombination and double strand staggered

102 breaks. Ectopic recombination generates inversions via a recombination event between two

103 homologous sequences oriented head to head in a sequence (Box 1 for further details; Box 1

104 - Fig. 1). Double strand staggered breaks can generate inversions via the complete 
105 detachment of a DNA fragment and its subsequent reattachment in the opposite

106 orientation (Box 1; Box 1 - Fig. 1). Most inversions are generated by this latter mechanism

107 (Ranz et al., 2007).

108 Both the mechanisms mentioned above can generate ample phenotypic effects by changing

109 the expression of a gene (or set of genes) at breakpoints (Fig. 2). Breakpoints can also create

110 chimeric genes (see glossary), which might sometimes have a beneficial effect. Indeed,

111 examples of the potential adaptive potential off chimeric genes are accumulating in a

112 diverse set of taxa (Carvunis et al., 2012; Guillén \& Ruiz, 2012; Jones et al., 2012; Stewart \&

113 Rogers, 2019). For example, in Drosophila mojavensis a chimeric gene at an inversion

114 breakpoint is associated with the detoxification of toxic compounds in cacti (Guillén \& Ruiz,

115 2012). Another example is found in the threespine stickleback Gasterosteus aculeatus,

116 where a gene located at an inversion breakpoint on chromosome XI harbors different exon

117 sequences depending on the inversion orientation, and is associated with differences in

118 muscular development between lake and oceanic phenotypes (Jones et al., 2012). While

119 speculative, an inversion breakpoint could create a new pleiotropic chimeric gene that

120 affects multiple traits. Moreover, the most common inversion mechanism (double strand

121 staggered breaks) often generate duplications at both breakpoints in the derived sequence

122 (Box1 - Fig. 1), allowing for the creation of chimeric gene without loss of the donor genes.

123 This property will also facilitate neo-functionalization of any gene duplicated by this

124 inversion generation mechanism.

125 As we will see below, direct evidence that breakpoint mutations drive supergene evolution

126 is scarce, but the mechanisms by which they might do so are established. With these 
considerations in place we turn to evaluating the role of suppressed recombination and

128 breakpoint mutation in the evolution of candidate examples of supergenes.

The supergene hypothesis: what is the evidence for recombination suppression among

\section{$130 \quad$ multiple loci controlling selected trait variation?}

131 A core assumption of the supergene hypothesis (i.e., that suppressed recombination is

132 advantageous) is that multiple, linked genetic variants control trait variation that differs

133 between inversion forms. In contrast, if variation is controlled by a single locus with

134 pleiotropic effects on several traits, suppressed recombination is not necessarily favored or required to explain the existence of discrete morphs that differ in these traits.

136 Our review of the literature revealed that we still know very little about the number,

137 location and identity of selected loci within candidate supergenes. This is not surprising

138 given that determining the number of adaptive loci within a region of suppressed recombination is difficult, because suppressed recombination frustrates attempts at fine-

140 scale genetic mapping. The presence of two or more selected loci in a supergene was

141 historically inferred from genetic crosses aimed at detecting rare recombinants (i.e.,

142 intermediate phenotypic forms) (Cain \& Sheppard, 1954; Mather, 1950). For example,

143 Mather described a genetic model where multiple selected loci locked within an inversion

144 control heterostyly in Primula sinensis, a classic example of a putative supergene (Mather, 145 1950). However, recent work using modern genomic approaches suggests that Mather's 146 simple genetic model is erroneous and needs modification (Li et al., 2016). Specifically, a

147178 kilo base-pair indel containing 5 predicted genes is associated with the different floral

148 types (Li et al., 2016), with one floral type being hemizygous for this segment and the other 149 completely lacking it (Table 1) (Li et al., 2016). 
150 A revision of the classic genetic model also occurred for the iconic land snail Cepaea

151 nemoralis (Table 1), where cryptic shell color-pattern was long thought to be associated

152 with five loci locked within an inversion (Cain \& Sheppard, 1954). Recent work showed an

153 absence of recombination in the putative supergene, casting doubt on the number and

154 linkage relationships of loci controlling shell color (Gonzalez, Aramendia, \& Davison, 2019).

155 These recent developments urge for more rigorous tests on the true number of selected

156 variants within supergenes and their precise genomic location(s).

157 Indeed, to our knowledge, the existence of multiple selected loci within a supergene

158 associated with an inversion has been demonstrated in only two systems, both plants (Table

159 1; Box 2). In addition, indirect but fairly convincing evidence exists in two insect systems.

160 Details of these example are contained in Box 2. Clearly, further work determining the 161 number of loci within inversions and candidate supergenes that contribute to trait variation

162 is warranted. In this regard, emerging techniques that allow functional genetic manipulation 163 of structural variants (e.g., CRISPR-Cas9) hold promise for making such progress (Hopkins,

164 Tyukmaeva, Gompert, Feder, \& Nosil; Kraft et al., 2015).

165 The breakpoint hypothesis: what is the evidence that functional loci reside in or near

166 inversion breakpoints?

167 A core assumption of the breakpoint hypothesis is that functional loci reside in or near

168 inversion breakpoints. We found indications for this hypothesis in three systems (Papilio 169 polytes, Solenopsis invicta and Timema cristinae), but expect this number to increase when 170 breakpoint characterization is completed in more systems (Table 1).

171 In the mimetic butterfly Papilio polytes, an inversion breakpoint disrupts a transcriptional 172 regulator and affects the expression in embryonic wings of three neighboring genes 
173 potentially involved in wing color-pattern development (UXT, U3T and prospero; Table 1)

174 (Nishikawa et al., 2015). In the fire ant Solenopsis invicta, a region of reduced recombination

175 generated via three successive inversions (Yan et al., 2020) is associated with different social

176 structures of colonies (Wang et al., 2013). A breakpoint of the second inversion is increasing

177 the expression of a neighboring gene (SI2.2.0_02248), which is a strong candidate to explain

178 differences in colony social structures (Huang, Dang, Chang, \& Wang, 2018; Yan et al., 2020).

179 In Timema cristinae a massive deletion occurring at one likely breakpoint of a putative

180 inversion deleted multiple loci known to affect color in another species of the genus

181 (Villoutreix et al., 2020).

182 Interestingly, with the exception of Timema cristinae, indications of putative selected loci

183 within the inversion at locations other than the breakpoint exist for these systems. We

184 discuss the implication of this observation in the following section.

\section{The breakpoint-linkage hypothesis and implications for evolutionary dynamics}

186 As mentioned previously, the supergene and breakpoint-mutation hypotheses are not mutually exclusive. The selective advantage of an inversion could come from its property of impeding recombination between at least one locus within the inversion and a favorable

189 breakpoint mutation. We refer to this mixed hypothesis as the breakpoint-linkage

190 hypothesis (see glossary), which predicts that loci controlling trait variation will be localized

191 both at one (or both) breakpoint(s) and within the inversion.

192 In theory, this hypothesis could involve different processes and dynamics compared to the

193 classic supergene hypothesis. A supergene composed of a selected locus within an inversion

194 and an adaptive breakpoint mutation suggests two possible evolutionary scenarios. First,

195 pre-existing genetic variants within the inversion could become associated with a new 
adaptive breakpoint mutation. Although formal modeling is required, it is possible that such

197 a coupling could help relax some of the restrictions of a model based strictly on suppressed

198 recombination (Kirkpatrick \& Barton, 2006). For example, such coupling might mean that

199 the initial inversion needs not to capture essentially all favorable segregating alleles in the

200 correct linkage phase with one another. Instead, such sorting could occur after the initial

201 establishment of the inversion, with the initial establishment of the inversion being

202 dependent on the sum of adaptive values of the breakpoint and other genetic variants.

203 Second, an inversion could establish first because of an adaptive breakpoint mutation

204 (Guerrero, Rousset, \& Kirkpatrick, 2012), and subsequently evolve into a supergene by the emergence of additional genetic variants within it. This latter scenarios could be initiated in allopatry, where an inversion with an adaptive breakpoint sweeps to fixation and is selected

207 for its recombination suppressing properties only later upon secondary contact (or 208 introgression) and gene flow. In this latter case, allopatry allows for the evolution and capture of alternative sets of favorable alleles in alternate arrangements, by passing

210 difficulties of the supergene emergence when gene flow occurs and adaptive alleles are 211 segregating within populations (Feder, Gejji, Powell, \& Nosil, 2011).

212 In terms of empirical evidence, we found indications for the breakpoint-linkage hypothesis 213 in two systems (Table 1). In the mimetic butterfly Papilio polytes, an inversion contains a

214 locus shown to affect wing color-pattern (doublesex) and a breakpoint mutation affecting 215 the expression of three other genes potentially also affecting wing color-pattern (UXT, U3T 216 and prospero) (Kunte et al., 2014; Nishikawa et al., 2015). In the fire ant Solenopsis invicta, a 217 region of reduced recombination generated via three successive inversions contains a 218 strong candidate gene for odor generation/reception (Gp-9), a mechanisms at the root of 
social structure differences in fire ants (Wang et al., 2013). A breakpoint of the second

220 inversion increase the expression of another strong candidate gene for odor reception

221 (SI2.2.0_02248) (Huang et al., 2018; Yan et al., 2020).

222 While functional work is needed to better elucidate the role of these different loci in $P$. polytes and S. invicta, these two systems highlight the possibility for breakpoints to be one of several selected loci of a supergene. The vast majority of candidate supergene systems still lack a complete characterization of inversion breakpoints (usually one breakpoint is characterized but not the other; Table 1). For this reason we expect more systems to support the breakpoint-linkage hypothesis after further investigation.

\section{Future directions}

Future work could usefully focus on two directions. First, better information on the number,

230 location and identify of loci controlling trait variation within inversion is required. This can

231 be achieved using crosses to create recombinant forms, as for the two plant examples

232 discussed in Box 2. The regions identified with this technique are likely still large, and the number of loci identified here is likely to be an under-estimation. Moreover, the identification of causal variants at breakpoints will be challenging as many variants will be

235 linked due to the lack of recombination at breakpoints (Hoffmann \& Rieseberg, 2008; Matzkin, Merritt, Zhu, \& Eanes, 2005). Alternatively to controlled crosses, genome wide association mapping can be applied in species that exhibit more continuous variation in the same traits as those of close relatives with discrete morphs and inversions, but that lack inversion polymorphism. This will yield more precise estimates, but need to be complemented with functional manipulation in the species with the inversion. Ultimately,

241 functional transformations such as those offered by CRISPR-Cas9 may be required to 
242 precisely and firmly establish the variants functionally contributing to trait variation,

243 possibly by 'engineering' recombinant alleles to validate the independent effects of a given

244 variant on trait variation (Hopkins et al.; Kraft et al., 2015).

245 Second, once the selected loci within the inversion are identified, further work can be

246 implemented to characterize supergene origin, more specifically to test if the genetic

247 variants locked in the inversion predated the inversion. To do so, we need to date the

248 inversion independently from the selected variants it contains. An estimation of inversion

249 age by averaging the divergence time over the whole inverted sequence is likely to

250 underestimate inversion age, possibly resulting in the erroneous conclusion that the

251 variants appearance predated the inversion. Indeed, recombination still occurs between

252 inverted segments, and will only be prevented for selected loci and breakpoints. To

253 circumvent this caveat, one can take advantage of a useful feature of most inversions:

254 duplication at breakpoints (Ranz et al., 2007). Dating the duplication event will allow one to

255 accurately date the inversion independently from its genomic content. Such dating could

256 also be done for genes within the inversion and near breakpoints, but this will be less

257 precise, depending on the amount a recombination they experience.

258 Such dating was shown to be effective in Heliconius numata butterflies (Jay et al., 2018). It

259 requires sequence-level characterization of breakpoints, a difficult endeavor because

260 breakpoints often reside in highly repetitive regions of the genomes (Russell B. Corbett-

261 Detig et al., 2019; da Silva et al., 2019), which are difficult to assemble using short

262 sequencing read technologies (Fig. 3A). Nonetheless, creative approaches such as those

263 applied by Corbett-Detig and colleagues in Drosophila (Russell B. Corbett-Detig \& Hartl,

264 2012) hold promise (Fig. 3B), as do long reads technologies such as Nanopore and PacBio. 
266 Rapidly emerging candidate supergenes systems urge a careful assessment of the state of

267 research in this field. We outlined how inversions can facilitate supergene evolution either

268 via suppressed recombination or by inducing adaptive mutation at breakpoints. To our

269 knowledge, definitive evidence for the existence of multiple selected loci within candidate

270 supergenes has only been gathered in two systems. Thus direct evidence even for the classic

271 supergene hypothesis is still scarce, although many examples are consistent with this idea.

272 Little is known about the origin of supergenes, specifically if genetic variants or inversion

273 appeared first. As an alternative or in addition to the supergene hypothesis, inversions may

274 spread due to adaptive breakpoint mutations. Observations in multiple candidate

275 supergenes suggest a joint role for suppressed recombination and breakpoint mutation in

276 supergene evolution. Thus, further tests of the breakpoint-linkage hypothesis are

277 warranted. Distinguishing and confirming the role of breakpoints in supergene evolution will

278 likely require characterization of inversion breakpoints at the sequence level, which has yet

279 to be completed in most systems. We propose that further study of inversion breakpoints

280 will facilitate understanding the origin and maintenance of complex, discrete phenotypic

281 forms in nature, and the dynamics by which supergenes evolve. Although we focused here

282 on morphs, similar processes could apply to the evolution of other discrete units of diversity

283 such as ecotypes, species, sexes. 
285 Breakpoint-linkage hypothesis: the selective advantage to an inversion stems from both a 286 favorable effect of mutation at one of its breakpoint and the recombination suppression

287 between this mutation and at least one other selected variant within the inversion.

288 Breakpoint-mutation hypothesis (also referred as 'position effect hypothesis' in the

289 literature): the selective advantage to an inversion stems from a favorable effect(s)

290 associated with a mutation at one or both of its breakpoints.

291 Candidate supergene: case where multiple co-varying and discrete phenotypes are

292 associated with an inversion; the existence of multiple loci associated with these traits must

293 be demonstrated to advance the example from a candidate to a bonafide supergene.

294 Chimeric gene: a new gene constituted of sequences not previously associated together, for 295 example of parts of two genes, or parts of genes and non-coding DNA. Here, we consider 296 cases where the different DNA segments are brought together by an inversion breakpoint 297 (see Fig. 2B).

298 Chromosomal inversion: a chromosomal rearrangement in which a segment of a

299 chromosome is reversed end to end. This causes the inverted segment to have an opposite

300 sequence order from the ancestral sequence and reduces recombination in inversion

301 heterozygotes. Recombination is especially reduced near chromosomal inversion

302 breakpoints.

303 Chromosomal inversion breakpoint (shortened to 'inversion breakpoint' or simply

304 'breakpoint' in the main text and hereafter): the position(s) on a chromosome where DNA sequence orientation shifts after the occurrence of a chromosomal inversion (i.e., the end of 
an inversion where the genome shifts from inverted back to collinear). An inversion

307 generally has two breakpoints.

308 (Chromosomal) breakpoint mutation: sequence modification(s) at breakpoints resulting

309 from a chromosomal inversion. Mutations may also occur near breakpoints after an

310 inversion has occurred, however, here, we refer here to changes associated with the

311 creation of the rearrangement itself.

312 Discrete morphs: individuals of the same species that exhibit discrete phenotypic

313 differences (e.g., in morphology, color, behavior, physiology, etc.). In this piece, we focus on

314 cases where morphs are differentiated by multiple co-varying phenotypic traits such that

315 multiple genes may be involved.

316 Supergene: a group of genes affecting different phenotypes so seldom separated by

317 crossing-over that in effect they operate as a single genetic entity (i.e., a non-recombining

318 locus). This end may be achieved by close genetic proximity on a chromosome (i.e., tight

319 physical linkage), by inclusion within an inversion, or by other molecular mechanisms

320 impeding crossing-over. This definition is modified from that of E. B. Ford (Ford, 1965).

321 Supergene hypothesis: supergenes evolve because suppressed recombination within them maintains favorable allelic combinations at multiple loci that control different traits.

323 Switch gene: A gene controlling the development of alternative discrete morphs. 


\section{Acknowledgements}

326 This manuscript greatly benefited from discussions with Pr. Russel Corbett-Detig, Pr. Angus

327 Davison, Pr. Haruhiko Fujiwara, Dr. Clemens Küpper, Pr. Cheng-Ruei Lee, Pr. Thomas

328 Mitchell-Olds and Dr. John Wang on their respective study systems. We are grateful to Pr.

329 Cheng-Ruei Lee for providing us photographs of Boechera stricta. We are grateful to Dr.

330 Venera Tyukmaeva for insights on CRISPR-Cas9 and functional genomics. R.V. and P.N. were

331 supported by a grant from the European Research Council (EE-Dynamics 770826,

332 https://erc.europa.eu/). D.A. was supported by an ANR grant (ANR-18-CE35-0002-01-

333 WILDING). M. J. was supported by an ANR grant (ANR-18-CE02-0019-02 supergène). Z. G.

334 was supported by the NSF (DEB 1638768). J. F. was supported by grants from the USDA NIFA

335 program and NSF. All authors contributed to writing the manuscript. The authors declare

336 having no competing interests.

337 
(A) Are inversions supergenes?

1) Supergene hypothesis

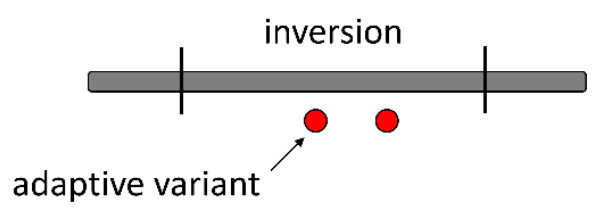

2) Breakpoint hypothesis

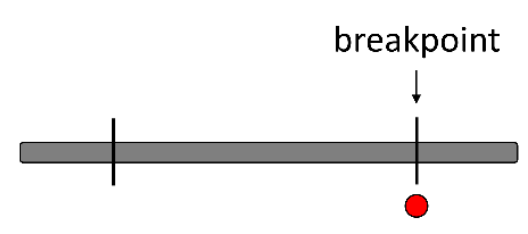

3) Breakpoint-linkage hypothesis

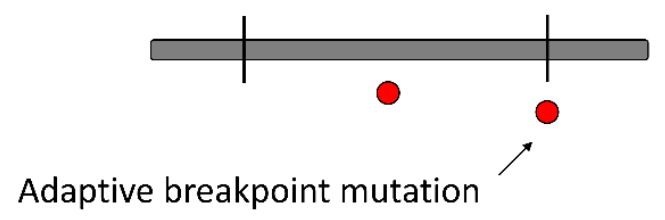

(B) Supergene origins.

1) variants first - inversion second

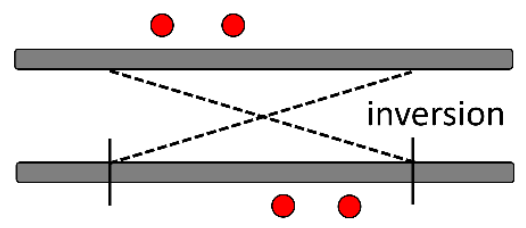

2) Inversion first - supergene second

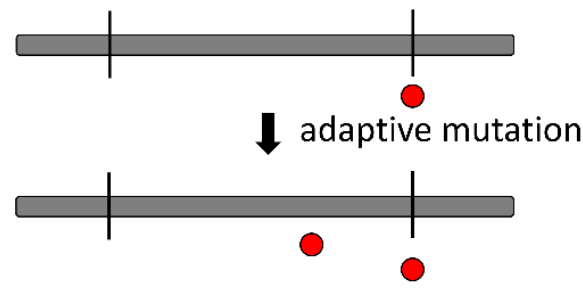

3) Inversion and supergene

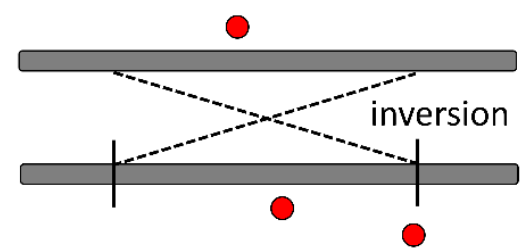

Figure 1- Hypotheses and evolutionary scenarios: A. Hypotheses behind inversion evolution. B. Evolutionary scenarios for supergene evolution. Grey squares represents a chromosome; red dots are divergently selected loci; black bars are inversion breakpoints. 
(A) Transcriptional changes.
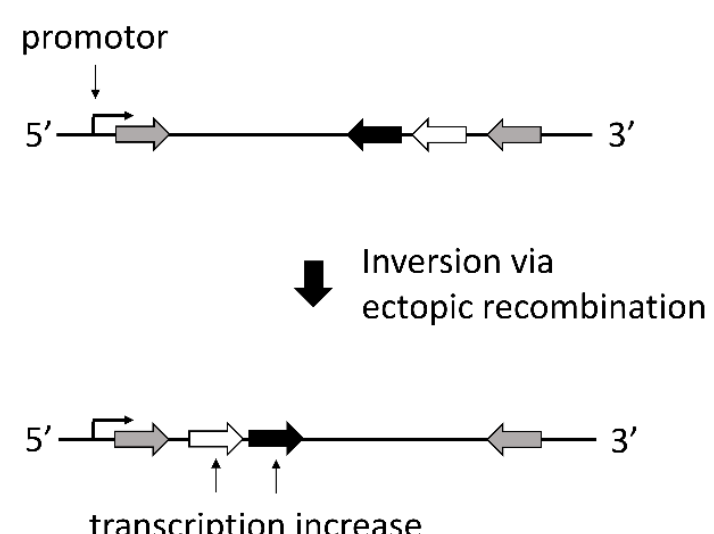

transcription increase
(B) Chimeric gene creation.

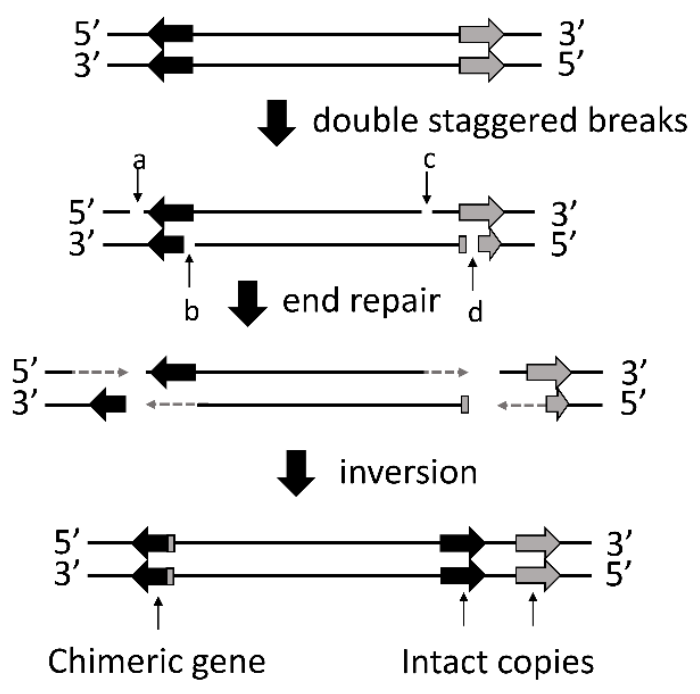

345 Figure 2-Possible mutations at inversion breakpoints: A. An inversion generated through 346 ectopic recombination put two genes into a different transcription context, altering their 347 level of expression. B. An inversion generated through the staggered break mechanism 348 generates a new chimeric switch gene, while avoiding gene loss via duplication. Arrow 349 represent genes, with orientation indicated via arrow direction; a, b, c, d represent single 350 strand breaks, resulting here in two staggered breaks. 


\section{(A) Misassembly of inversion breakpoint duplications}

Actual sequence of the derived conformation:

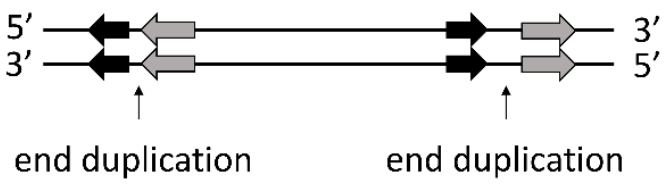

Assembly (short reads, 10X)

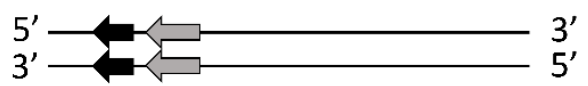

Figure 3-Characterizing breakpoint at the sequence level: A. Using short reads technologies can lead to misassembly of inversion breakpoints, for example due to duplications generated through the staggered breaks mechanisms (Ranz et al., 2007). B. A method to characterize breakpoint sequences using a single reference genome and short read data, as developed by (Russell B. Corbett-Detig, Cardeno, \& Langley, 2012). Black arrows symbolize aligned reads on reference genome, while grey arrows symbolize their unaligned paired reads. Breakpoint sequence characterization is possible by using these read pairs to generate and de novo assembly of the region. Figure redrawn and modified

\section{(B) Characterizing breakpoints sequences.}

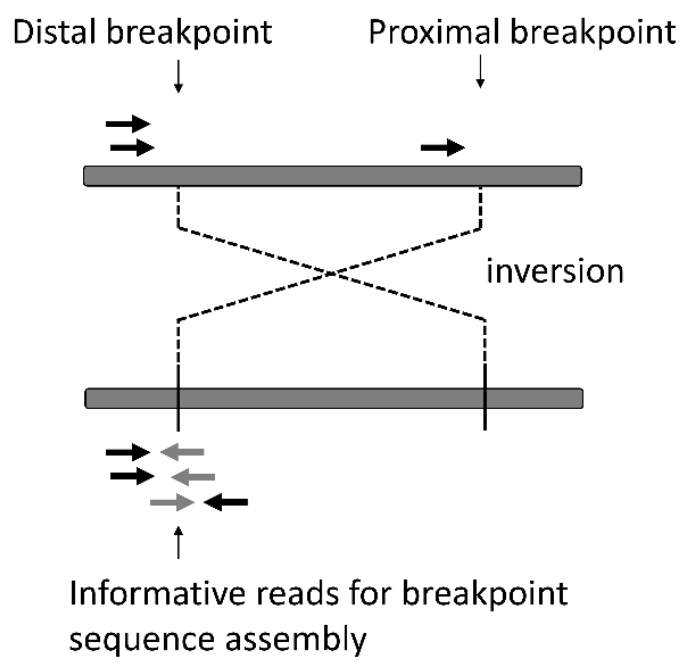



mutation.

We here discuss how inversions are formed and the associated effects of induced mutations on genetic variation at breakpoints. Two known molecular mechanisms can generate inversions: (1) ectopic recombination and, (2) double strand staggered breaks (Box 1. - Fig1) (Ling \& Cordaux, 2010; Ranz et al., 2007).

The first mechanism occurs from recombination between homologous sequences that are oriented head-to-head in the original sequence, subsequently resulting in inversion of the sequence located between these elements (Box 1 - Fig. 1A). This mechanism leaves little molecular traces and generates 'cut-and-paste' type breakpoints. The second mechanism involves double strand breaks occurring in two positions of the original sequences (Ranz et al., 2007). Such breaks are usually staggered, meaning that they will result in fragments with stretches of single stranded DNA at their extremities (Box 1. - Fig. 1B). The DNA repair mechanism that synthesize the reverse complement of these single stranded stretches then

377 join the DNA sequences back together in a non-homologous way, sometimes reinserting the DNA segment in the opposite orientation, creating an inversion. When the breaks are heavily staggered (i.e., with long single strand stretches) this results in inversions with duplicated sequences at both breakpoints in the derived sequence (Box 1. - Fig. 1B) (Ranz et al., 2007). In contrast, when the breaks are blunt or lightly staggered, 'cut-and-paste' type breakpoints without duplications are created in the derived sequence.

Despite these clear mechanisms of inversion formation, we still know very little about genetic variation at breakpoints and the mutations that breakpoint generates (Table 1). This 
386 (Russell B. Corbett-Detig et al., 2019; da Silva et al., 2019) which are difficult to sequence 387 and assemble and thus challenging to study (Fig. 3A). Nonetheless, some progress has been 388 made in Drosophila spp. (R. B. Corbett-Detig, 2016; Russell B. Corbett-Detig \& Hartl, 2012; 389 McBroome, Liang, \& Corbett-Detig, 2020; Ranz et al., 2007), where double strand staggered 390 breaks appear to be the most common mechanism generating inversions, very often 391 resulting in duplications at breakpoints (Ranz et al., 2007).

392 We note, however, that locating breakpoints is not sufficient to identify their phenotypic 393 effects. Obtaining the derived sequence is necessary to try to understand possible 394 phenotypic effects. This is not a straightforward task, as disruption of gene sequence by 395 breakpoints can sometimes leads to increase in their expression as seen in fire ants (Yan et 396 al., 2020). Nonetheless, phenotypic effects are expected, for example because both the 397 aforementioned mechanisms can change the expression context of set of genes (Fig. 2A). In 398 addition, the double strand staggered breaks mechanism can have another potential effect, 399 in which duplications of sequences leads to the creation of a new chimeric gene. This occurs 400 via merging the initial part of a gene with another coding sequence such as another gene or 401 pseudo-gene (Fig. 2B). This phenomenon can happen without the loss of the originally 402 disrupted genes (via their duplication), mitigating costs.

403

404 Thus, there are several possibilities by which breakpoints can create genetic variation with 405 likely phenotypic effects. The observation that similar genomic regions are often re-used 406 repeatedly as breakpoints for different inversions, including in different taxa, raised the

407 possibility for a recurrent and even somewhat predictable role for breakpoints in evolution 408 (Pevzner \& Tesler, 2003). 
(A) Ectopic recombination. Cut and paste breakpoint.

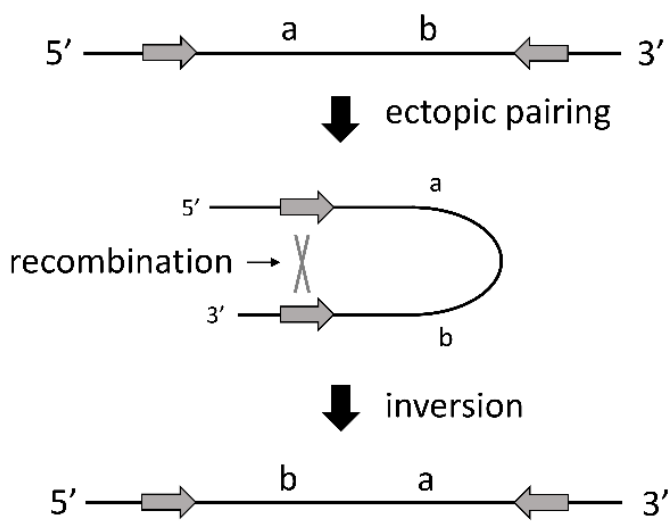

(B) Staggered breaks. Duplication at both ends.

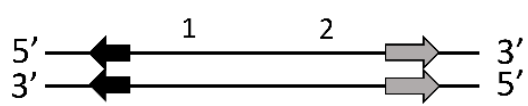

$\checkmark$ double staggered breaks
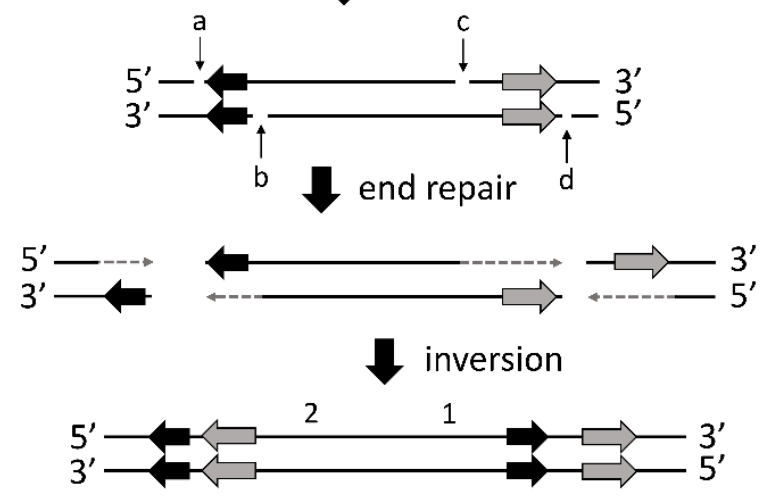

410 Box 1 - Figure 1 - Known molecular mechanisms generating inversions: Black and grey

411 arrows represent genes, with orientation indicated by the direction of the arrow $\mathbf{A}$. Ectopic

412 recombination between similar elements (transposable elements or duplicated genes) in

413 opposite orientation in a DNA segment leads to the inversion of the interspacing sequence.

414 B. Fours single strand breaks (a, b, c, and d) lead to two staggered breaks. Through end

415 repair and reattachment in the opposite orientation an inversion in generated with

416 sequence duplication at both breakpoints (black and grey genes). 
419 Despite seventy years of research on supergene, evidence for the existence of multiple selected loci within an inversion has only been gathered in a handful of systems.

421 Evidence for multiple loci controlling trait variation within an inversion has been demonstrated in Boechera stricta (Box 2 - Fig. 1A), a perennial plant from the Rocky Mountains. Here, two subspecies adapted to different climates have entered in secondary contact (Lee et al., 2017). The subspecies differ in multiple traits and through crosses it was demonstrated that three different QTL are associated with these divergent traits (Box 2 Fig. 2B). Interestingly, the inversion itself has an effect on these traits, independent of the genotype at the three QTL, but the reason for this is unknown. This supergene has also had its evolutionary origins characterized such that it is known that the inversion is relatively young and likely evolved after secondary contact (Lee et al., 2017). The existence of multiple

430 selected loci within an inversion has also been demonstrated, again via crosses, in the Mimulus guttatus species complex, where two life strategies (perennial vs annual) are maintained through divergent selection (Lowry \& Willis, 2010). Specifically, through crosses between the Mimulus guttatus annual type and a closely related perennial species with a

434 collinear gene order, Mimulus tilingii, Coughlan and Willis (Coughlan \& Willis, 2018) identified two QTL within the inversion associated with the traits experiencing divergent selection.

437 Less direct, but reasonably strong, evidence for multiple loci has also been reported in two 438 insect systems (Table 1). Here, the approach was to compare the genetic basis of traits in 439 closely related taxa that exhibit versus lack inversion polymorphism. In the polymorphic 440 butterfly Heliconius numata a region of reduced recombination generated via multiple 
441 successive inversions control variation in color morphs. The same genomic region is known

442 to contain at least three recombining loci associated with color variation in other species of

443 the genus (Box 1 - Fig. 1D) (Huber et al., 2015; Mathieu Joron et al., 2011; Van Belleghem et 444 al., 2017). It is therefore likely that the inversion in $H$. numata harbor variants at these three 445 loci that recombine in other Heliconius species. A similar example stems from Timema, a 446 genus of stick insect that is endemic of the western USA and Mexico and that shows within-

447 population variation for cryptic coloration (i.e., green versus melanistic morphs). In several 448 species, morphs are highly discrete and controlled by a region of suppressed recombination

449 on the linkage group eight (named 'Mel-Stripe') (Nosil et al., 2018; Villoutreix et al., 2020).

450 However, a recent study in a species displaying more quantitative color variation (Timema

451 chumash) revealed that multiple genetic variants, and likely multiple genes within Mel-

452 Stripe, control color variation (Villoutreix et al., 2020). 


\section{(A) Boechera stricta}

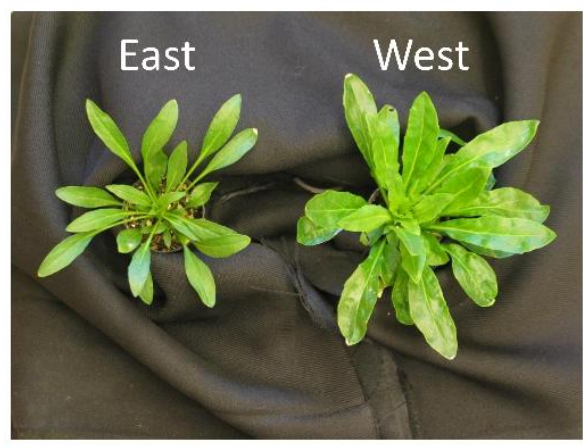

(C) H. numata aposematic morphs
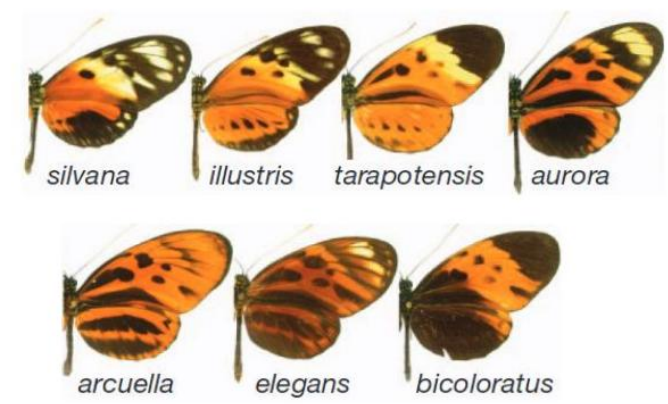

(B) Multiple QTL within Bs1 inversion

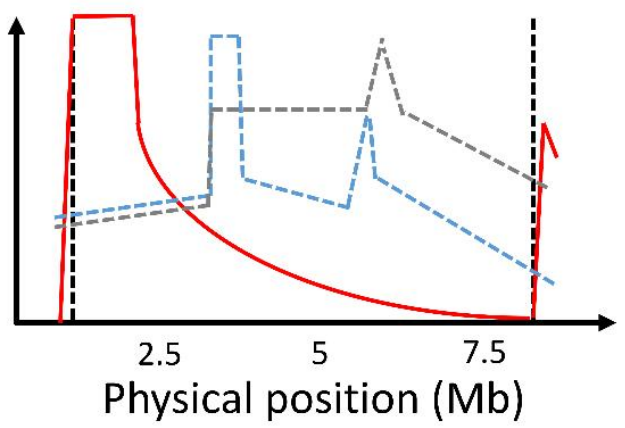

(D) H. numata colour supergene

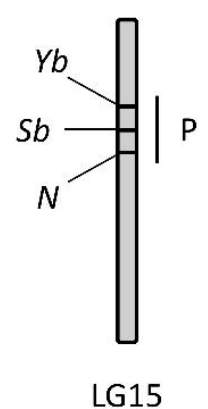

Box 2 - Figure 1 - Flagship examples of supergenes: A. Boechera stricta subspecies types. The East subspecies has smaller leaves with more trichomes. Photo credit: Cheng-Ruei Lee. B. Multiple QTL were detected in the Bs1 inversion. The red, blues dashed and grey dashed lines correspond to different composited traits obtained through discriminant function analysis. See (Lee et al., 2017) for more details. Black dashed lines correspond to inversion breakpoint positions. Breakpoint are of cut-and-paste type for the Bs1 inversion. Figure redrawn and modified with the permission of the authors. C. Heliconius numata aposematic morphs, involved in Müllerian mimicry rings with other butterflies. D. Aposematic morphs in $H$. numata are associated with an inversion (named P) on linkage group LG15, encompassing at least three loci associated with aposematic color morph in $\mathrm{H}$. melpomene: $\mathrm{Yb}, \mathrm{Sb}$ and $\mathrm{N}$. 


\begin{tabular}{|c|c|c|c|c|c|c|c|c|}
\hline Species & $\begin{array}{l}\text { Multiple } \\
\text { traits? }\end{array}$ & $\begin{array}{l}\text { Selection on } \\
\text { phenotypes? }\end{array}$ & $\begin{array}{l}\text { Map to an } \\
\text { inversion? }\end{array}$ & $\begin{array}{l}\text { Multiple } \\
\text { loci? }\end{array}$ & $\begin{array}{l}\text { Selection on } \\
\text { recomb. } \\
\text { sup.? }\end{array}$ & $\begin{array}{l}\text { Adaptive } \\
\text { breakpoint } \\
\text { mutation? }\end{array}$ & $\begin{array}{l}\text { Breakpoints } \\
\text { sequence? }\end{array}$ & $\begin{array}{l}\text { Variants } \\
\text { first? }\end{array}$ \\
\hline \multicolumn{9}{|l|}{ Aves } \\
\hline $\begin{array}{l}\text { Ruff - Philomachus } \\
\text { pugnax }\end{array}$ & $\begin{array}{l}\text { Yes. } \\
\text { (Kupper et } \\
\text { al., 2016; } \\
\text { Lamichhan } \\
\text { ey et al., } \\
\text { 2016) }\end{array}$ & $\begin{array}{c}\text { Possibly. } \\
\text { (Kupper et al., } \\
\text { 2016; } \\
\text { Lamichhaney } \\
\text { et al., 2016) }\end{array}$ & $\begin{array}{c}\text { Yes. } \\
\text { (Kupper et al., } \\
\text { 2016; } \\
\text { Lamichhaney et } \\
\text { al., 2016) }\end{array}$ & $\begin{array}{l}\text { Likely. } \\
\text { (Kupper et } \\
\text { al., 2016; } \\
\text { Lamichhane } \\
\text { y et al., } \\
\text { 2016) }\end{array}$ & Not tested. & $\begin{array}{l}\text { No. } \\
\text { Counter- } \\
\text { selected. } \\
\text { (Kupper et } \\
\text { al., 2016; } \\
\text { Lamichhan } \\
\text { ey et al., } \\
\text { 2016) }\end{array}$ & $\begin{array}{c}\text { Yes. } \\
\text { (Kupper et } \\
\text { al., 2016; } \\
\text { Lamichhane } \\
\text { y et al., } \\
\text { 2016) }\end{array}$ & Not known. \\
\hline $\begin{array}{l}\text { White-throated } \\
\text { sparrow - } \\
\text { Zonotrichia } \\
\text { albicollis }\end{array}$ & $\begin{array}{l}\text { Yes. } \\
\text { (Tuttle et } \\
\text { al., 2016) }\end{array}$ & $\begin{array}{c}\text { Yes. } \\
\text { (Tuttle et al., } \\
\text { 2016) }\end{array}$ & $\begin{array}{c}\text { Yes. } \\
\text { (Thomas et al., } \\
\text { 2008; } \\
\text { Thorneycroft, } \\
\text { 1966; } \\
\text { Throneycroft, } \\
\text { 1975; Tuttle et } \\
\text { al., 2016) }\end{array}$ & $\begin{array}{l}\text { Likely. } \\
\text { (Tuttle et } \\
\text { al., 2016) }\end{array}$ & Not tested. & $\begin{array}{c}\text { Not } \\
\text { known. }\end{array}$ & No. & Not known. \\
\hline
\end{tabular}

Invertebrates 


\begin{tabular}{|c|c|c|c|c|c|c|c|c|}
\hline $\begin{array}{l}\text { Anopheles - } \\
\text { Anopheles } \\
\text { gambiae }\end{array}$ & $\begin{array}{l}\text { Possibly. } \\
\text { (Cheng, } \\
\text { Tan, Hahn, } \\
\text { \& } \\
\text { Besansky, } \\
\text { 2018) }\end{array}$ & $\begin{array}{c}\text { Possibly. } \\
\text { (Fouet, Gray, } \\
\text { Besansky, \& } \\
\text { Costantini, } \\
\text { 2012; Gray, } \\
\text { Rocca, } \\
\text { Costantini, \& } \\
\text { Besansky, } \\
\text { 2009; Rocca, } \\
\text { Gray, } \\
\text { Costantini, \& } \\
\text { Besansky, } \\
\text { 2009) }\end{array}$ & $\begin{array}{c}\text { Yes. } \\
\text { (Cheng et al., } \\
\text { 2018; Coluzzi, } \\
\text { Sabatini, della } \\
\text { Torre, Di Deco, \& } \\
\text { Petrarca, 2002; } \\
\text { Coluzzi, Sabatini, } \\
\text { Petrarca, \& Di } \\
\text { Deco, 1979; } \\
\text { Fouet et al., } \\
\text { 2012; Gray et al., } \\
\text { 2009; Rocca et } \\
\text { al., 2009) }\end{array}$ & $\begin{array}{l}\text { Possibly. } \\
\text { (Cheng et } \\
\text { al., 2012) }\end{array}$ & Not tested. & No. & $\begin{array}{c}\text { Partly } \\
\text { characterize } \\
\text { d. } \\
\text { (Cheng et } \\
\text { al., 2018; } \\
\text { Sharakhov } \\
\text { et al., 2006) }\end{array}$ & Not known. \\
\hline $\begin{array}{l}\text { Grove snail - } \\
\text { Cepaea nemoralis }\end{array}$ & $\begin{array}{c}\text { Yes. } \\
\text { (Cain \& } \\
\text { Sheppard, } \\
\text { 1950, } \\
\text { 1952) }\end{array}$ & $\begin{array}{l}\text { Possibly. } \\
\text { (Cain \& } \\
\text { Sheppard, } \\
\text { 1950, 1954; } \\
\text { Cameron \& } \\
\text { Cook, 2012) }\end{array}$ & $\begin{array}{l}\text { Not known. } \\
\text { (Gonzalez et al., } \\
\text { 2019) }\end{array}$ & Not known. & Not known. & $\begin{array}{c}\text { Not } \\
\text { known. }\end{array}$ & No. & Not known. \\
\hline $\begin{array}{l}\text { Numata longwing - } \\
\text { Heliconius numata }\end{array}$ & $\begin{array}{c}\text { Yes. } \\
\text { (Mathieu } \\
\text { Joron et } \\
\text { al., 2011) }\end{array}$ & $\begin{array}{c}\text { Yes. } \\
\text { (Benson, 1972; } \\
\text { Chouteau, } \\
\text { Llaurens, } \\
\text { Piron-Prunier, } \\
\text { \& Joron, 2017; } \\
\text { M. Joron, }\end{array}$ & $\begin{array}{c}\text { Yes. } \\
\text { (Mathieu Joron } \\
\text { et al., 2011). }\end{array}$ & $\begin{array}{l}\text { Very likely. } \\
\text { (Huber et } \\
\text { al., 2015; } \\
\text { Mathieu } \\
\text { Joron et al., } \\
\text { 2011; Van } \\
\text { Belleghem }\end{array}$ & Not tested. & No. & $\begin{array}{c}\text { Partly } \\
\text { characterize } \\
\text { d. } \\
\text { (Jay et al., } \\
\text { 2018) }\end{array}$ & Not known. \\
\hline
\end{tabular}




\begin{tabular}{|c|c|c|c|c|c|c|c|c|}
\hline & & $\begin{array}{l}\text { Wynne, Lamas, } \\
\text { \& Mallet, 1999; } \\
\text { Kapan, 2001; } \\
\text { Mallet \& } \\
\text { Barton, 1989; } \\
\text { Merrill et al., } \\
\text { 2012) }\end{array}$ & & et al., 2017) & & & & \\
\hline $\begin{array}{l}\text { Common Mormon } \\
\text { - Papilio polytes }\end{array}$ & $\begin{array}{l}\text { Yes. } \\
\text { (Kunte et } \\
\text { al., 2014; } \\
\text { Nishikawa } \\
\text { et al., } \\
\text { 2015) }\end{array}$ & $\begin{array}{c}\text { Yes. } \\
\text { (Clarke \& } \\
\text { Sheppard, } \\
\text { 1972) }\end{array}$ & $\begin{array}{c}\text { Yes. } \\
\text { (Kunte et al., } \\
\text { 2014; Nishikawa } \\
\text { et al., 2015) }\end{array}$ & $\begin{array}{l}\text { Likely. } \\
\text { (Nishikawa } \\
\text { et al., 2015) }\end{array}$ & Not tested. & $\begin{array}{l}\text { Possibly. } \\
\text { (Nishikawa } \\
\text { et al., } \\
\text { 2015) }\end{array}$ & $\begin{array}{c}\text { Yes. } \\
\text { (Nishikawa } \\
\text { et al., 2015) }\end{array}$ & Not known. \\
\hline $\begin{array}{l}\text { Fire ant - } \\
\text { Solenopsis invicta }\end{array}$ & $\begin{array}{l}\text { Yes. } \\
\text { (Wang et } \\
\text { al., 2013). }\end{array}$ & $\begin{array}{c}\text { Possibly. } \\
\text { (Ross \& Keller, } \\
\text { 1995) }\end{array}$ & $\begin{array}{c}\text { Yes. } \\
\text { (Wang et al., } \\
\text { 2013) }\end{array}$ & $\begin{array}{l}\text { Possibly. } \\
\text { (Wang et al., } \\
\text { 2013) }\end{array}$ & Not tested. & $\begin{array}{l}\text { Possibly. } \\
\text { (Huang et } \\
\text { al., 2018; } \\
\text { Yan et al., } \\
\text { 2020) }\end{array}$ & $\begin{array}{c}\text { Yes. } \\
\text { (Yan et al., } \\
\text { 2020) }\end{array}$ & Not known. \\
\hline $\begin{array}{l}\text { Timema walking } \\
\text { sticks - Timema } \\
\text { cristinae. }\end{array}$ & $\begin{array}{c}\text { Yes. } \\
\text { (Comeault } \\
\text { et al., } \\
\text { 2015) }\end{array}$ & $\begin{array}{c}\text { Yes. } \\
\text { (Cristina P. } \\
\text { Sandoval, } \\
\text { 1994; C. P. } \\
\text { Sandoval \& } \\
\text { Nosil, 2005) }\end{array}$ & $\begin{array}{c}\text { Likely. } \\
\text { (Villoutreix et al., } \\
\text { 2020) }\end{array}$ & $\begin{array}{l}\text { Very likely. } \\
\text { (Villoutreix } \\
\text { et al., 2020) }\end{array}$ & Not tested. & $\begin{array}{l}\text { Likely. } \\
\text { (Villoutreix } \\
\text { et al., } \\
2020 \text { ) }\end{array}$ & $\begin{array}{c}\text { Partly } \\
\text { characterize } \\
\text { d. } \\
\text { (Nosil et al., } \\
2018 ; \\
\text { Villoutreix et } \\
\text { al., 2020) }\end{array}$ & Not known. \\
\hline
\end{tabular}




\begin{tabular}{|c|c|c|c|c|c|c|c|c|}
\hline \multicolumn{9}{|l|}{ Mammals } \\
\hline $\begin{array}{l}\text { Humans - Homo } \\
\text { sapiens }\end{array}$ & $\begin{array}{c}\text { Yes. } \\
\text { (Puig, } \\
\text { Casillas, } \\
\text { Villatoro, } \\
\text { \& Caceres, } \\
\text { 2015; } \\
\text { Stefansson } \\
\text { et al., } \\
\text { 2005) }\end{array}$ & $\begin{array}{l}\text { Likely. } \\
\text { (Stefansson et } \\
\text { al., 2005) }\end{array}$ & $\begin{array}{c}\text { Yes } \\
\text { (Puig et al., } \\
\text { 2015; Stefansson } \\
\text { et al., 2005) }\end{array}$ & $\begin{array}{l}\text { Possibly } \\
\text { (Puig et al., } \\
\text { 2015) }\end{array}$ & Not tested. & $\begin{array}{l}\text { Possibly. } \\
\text { (de Jong et } \\
\text { al., 2012) }\end{array}$ & $\begin{array}{l}\text { Yes. } \\
\text { (Stefansson } \\
\text { et al., 2005) }\end{array}$ & Not known. \\
\hline \multicolumn{9}{|l|}{ Plants } \\
\hline $\begin{array}{l}\text { Drummond's } \\
\text { rockcress - } \\
\text { Boechera stricta }\end{array}$ & $\begin{array}{l}\text { Yes. } \\
\text { (Lee et al., } \\
\text { 2017) }\end{array}$ & $\begin{array}{c}\text { Yes. } \\
\text { (Anderson, } \\
\text { Lee, \& } \\
\text { Mitchell-Olds, } \\
\text { 2011; } \\
\text { Anderson, Lee, } \\
\text { Rushworth, } \\
\text { Colautti, \& } \\
\text { Mitchell-Olds, } \\
\text { 2013; Lee et } \\
\text { al., 2017) }\end{array}$ & $\begin{array}{c}\text { Yes. } \\
\text { (Lee et al., 2017) }\end{array}$ & $\begin{array}{l}\text { Yes. } \\
\text { (Lee et al., } \\
\text { 2017) }\end{array}$ & $\begin{array}{c}\text { Yes, but } \\
\text { debated. } \\
\text { (Charleswort } \\
\text { h \& Barton, } \\
\text { 2018; Lee et } \\
\text { al., 2017) }\end{array}$ & $\begin{array}{l}\text { No. } \\
\text { (Lee et al., } \\
\text { 2017). }\end{array}$ & $\begin{array}{l}\text { Yes. } \\
\text { (Lee et al., } \\
\text { 2017). }\end{array}$ & Yes. \\
\hline
\end{tabular}




\begin{tabular}{|c|c|c|c|c|c|c|c|c|}
\hline $\begin{array}{l}\text { Common yellow } \\
\text { monkeyflower - } \\
\text { Mimulus guttatus } \\
\text { species complex }\end{array}$ & $\begin{array}{c}\text { Yes. } \\
\text { (Coughlan } \\
\text { \& Willis, } \\
\text { 2018; } \\
\text { Lowry \& } \\
\text { Willis, } \\
\text { 2010) }\end{array}$ & $\begin{array}{c}\text { Yes. } \\
\text { (Lowry \& } \\
\text { Willis, 2010) }\end{array}$ & $\begin{array}{c}\text { Yes. } \\
\text { (Coughlan \& } \\
\text { Willis, 2018; } \\
\text { Lowry \& Willis, } \\
\text { 2010) }\end{array}$ & $\begin{array}{l}\text { Yes. } \\
\text { (Coughlan } \\
\text { \& Willis, } \\
\text { 2018) }\end{array}$ & Not tested. & $\begin{array}{c}\text { Not } \\
\text { known. }\end{array}$ & No. & Not known. \\
\hline $\begin{array}{l}\text { Primrose - Primula } \\
\text { sp. }\end{array}$ & $\begin{array}{l}\text { Yes. } \\
\text { (Darwin, } \\
\text { 1862) }\end{array}$ & $\begin{array}{c}\text { Likely. } \\
\text { (Piper \& } \\
\text { Charlesworth, } \\
\text { 2008) }\end{array}$ & $\begin{array}{c}\text { No. } \\
\text { (Li et al., 2016) }\end{array}$ & $\begin{array}{l}\text { Possibly. } \\
\text { (Li et al., } \\
\text { 2016) }\end{array}$ & Not tested. & $\begin{array}{l}\text { N.A. Indel. } \\
\text { (Li et al., } \\
\text { 2016) }\end{array}$ & $\begin{array}{l}\text { Yes. } \\
\text { (Li et al., } \\
\text { 2016) }\end{array}$ & N. A. \\
\hline
\end{tabular}

Teleosts

\begin{tabular}{|c|c|c|c|c|c|c|c|c|}
\hline $\begin{array}{l}\text { Atlantic Cod - } \\
\text { Gadus morhua. }\end{array}$ & $\begin{array}{l}\text { Yes. } \\
\text { (Berg et } \\
\text { al., 2016; } \\
\text { Sinclair- } \\
\text { Waters et } \\
\text { al., 2018) }\end{array}$ & $\begin{array}{l}\text { Likely. } \\
\text { (Berg et al., } \\
\text { 2016; Sinclair- } \\
\text { Waters et al., } \\
\text { 2018) }\end{array}$ & $\begin{array}{c}\text { Yes. } \\
\text { (Berg et al., } \\
\text { 2016; } \\
\text { Kirubakaran et } \\
\text { al., 2016; } \\
\text { Sinclair-Waters } \\
\text { et al., 2018) }\end{array}$ & $\begin{array}{l}\text { Possibly. } \\
\text { (Berg et al., } \\
\text { 2016; } \\
\text { Kirubakaran } \\
\text { et al., 2016; } \\
\text { Sinclair- } \\
\text { Waters et } \\
\text { al., 2018) }\end{array}$ & Not tested. & $\begin{array}{c}\text { Not } \\
\text { known. }\end{array}$ & No. & Not known. \\
\hline $\begin{array}{l}\text { Threespine } \\
\text { sticklebacks - } \\
\text { Gasterosteus } \\
\text { aculeatus }\end{array}$ & $\begin{array}{c}\text { Yes. } \\
\text { (Jones et } \\
\text { al., 2012) }\end{array}$ & $\begin{array}{c}\text { Likely. } \\
\text { (Jones et al., } \\
\text { 2012) }\end{array}$ & $\begin{array}{c}\text { Yes. } \\
\text { (Jones et al., } \\
\text { 2012) }\end{array}$ & $\begin{array}{l}\text { Possibly. } \\
\text { (Albert et } \\
\text { al., 2007; }\end{array}$ & Not tested. & $\begin{array}{c}\text { Yes. } \\
\text { (Jones et }\end{array}$ & $\begin{array}{c}\text { Yes. } \\
\text { (Jones et al., } \\
\text { 2012) }\end{array}$ & Not known. \\
\hline
\end{tabular}




\begin{tabular}{|c|c|c|c|c|c|c|c|c|}
\hline & & & & $\begin{array}{l}\text { Colosimo et } \\
\text { al., 2004) }\end{array}$ & & al., 2012) & & \\
\hline $\begin{array}{l}\text { Steelhead/rainbow } \\
\text { trout - } \\
\text { Oncorhynchus } \\
\text { mykiss }\end{array}$ & $\begin{array}{c}\text { Yes. } \\
\text { (Nichols, } \\
\text { Edo, } \\
\text { Wheeler, } \\
\& \\
\text { Thorgaard, } \\
\text { 2008; } \\
\text { Pearse, } \\
\text { Miller, } \\
\text { Abadia- } \\
\text { Cardoso, \& } \\
\text { Garza, } \\
\text { 2014) }\end{array}$ & Not tested. & $\begin{array}{c}\text { Possibly. } \\
\text { [(Nichols et al., } \\
\text { 2008; O'Malley, } \\
\text { Sakamoto, } \\
\text { Danzmann, \& } \\
\text { Ferguson, 2003; } \\
\text { Pearse et al., } \\
\text { 2014; Robison, } \\
\text { Wheeler, Sundin, } \\
\text { Sikka, \& } \\
\text { Thorgaard, 2001) }\end{array}$ & $\begin{array}{l}\text { Likely. } \\
\text { (Lemopoulo } \\
\text { s, Uusi- } \\
\text { Heikkilä, } \\
\text { Huusko, } \\
\text { Vasemägi, \& } \\
\text { Vainikka, } \\
\text { 2018) }\end{array}$ & Not tested. & $\begin{array}{c}\text { Not } \\
\text { known. }\end{array}$ & No. & Not known. \\
\hline
\end{tabular}

Table 1 - Examples of candidate supergene. Species: common and latin naming. Multiple traits: Does morphs different by multiple traits? Selection on phenotypes: Has selection on these traits been shown? Map to an inversion: Are these traits associated with and inversion? Multiple loci: Has the existence of multiple loci controlling the aforementioned traits been demonstrated in this system? Selection on recomb. sup.: Has the selective advantage of an inversion been demonstrated to come from its property of impeding recombination between multiple selected loci? Adaptive breakpoint mutation: Is their evidence for this inversion to be selected for or against because of one of its breakpoints. Breakpoint sequence: Have the breakpoints been characterized at the sequence level. Variants first?: Do adaptive variants in the putative supergene predate the origins of the inversion? 


\section{Bibliography}

478

479

480

481

482

483

484

485

486

487

488

489

490

491

492

493

494

495

496

497

498

499

500

501

502

503

504

505

506

507

Albert, A. Y. K., Sawaya, S., Vines, T. H., Knecht, A. K., Miller, C. T., Summers, B. R., . . . Schluter, D. (2007). The genetics of adaptative shape shift in stickleback: Pleiotropy and effect size. Evolution, 62(1), 76-85. Anderson, J. T., Lee, C. R., \& Mitchell-Olds, T. (2011). LifeHistory Qtls and Natural Selection on Flowering Time in Boechera Stricta, a Perennial Relative of Arabidopsis. Evolution, 65(3), 771-787. doi:10.1111/j.15585646.2010.01175.x

Anderson, J. T., Lee, C. R., Rushworth, C. A., Colautti, R. I., $\&$ Mitchell-Olds, T. (2013). Genetic trade-offs and conditional neutrality contribute to local adaptation. $\mathrm{Mol}$ Ecol, 22(3), 699-708. doi:10.1111/j.1365294X.2012.05522.x

Benson, W. W. (1972). Natural-Selection for Mullerian Mimicry in Heliconius-Erato in Costa-Rica. Science, 176(4037), 936-939. doi:DOI 10.1126/science.176.4037.936

Berg, P. R., Star, B., Pampoulie, C., Sodeland, M., Barth, J. M. I., Knutsen, H., . . J Jentoft, S. (2016). Three chromosomal rearrangements promote genomic divergence between migratory and stationary ecotypes of Atlantic cod. Scientific Reports, 6(23246). doi:10.1038/srep23246

Cain, A. J., \& Sheppard, P. M. (1950). Selection in the polymorphic land snail Cepæa nemoralis. Heredity, 4(3), 275-294. doi:10.1038/hdy.1950.22

Cain, A. J., \& Sheppard, P. M. (1952). The effects of natural selection on body colour in the land snail Cepaea 
nemoralis. Heredity, 6(2), 217-231.

doi:10.1038/hdy.1952.22

Cain, A. J., \& Sheppard, P. M. (1954). NATURAL SELECTION IN CEPAEA. Genetics, 39(1), 89-116.

Cameron, R., \& Cook, L. (2012). CORRELATED PHENOTYPIC RESPONSES TO HABITAT DIFFERENCE IN CEPAEA NEMORALIS (L.). FOLIA MALACOLOGICA, 20(4), 255-263.

Carvunis, A.-R., Rolland, T., Wapinski, I., Calderwood, M. A., Yildirim, M. A., Simonis, N., . . Vidal, M. (2012). Proto-genes and de novo gene birth. Nature, 487(7407), 370-374. doi:10.1038/nature11184

Charlesworth, B., \& Barton, N. H. (2018). The Spread of an Inversion with Migration and Selection. Genetics, 208(1), 377-382.

Cheng, C. D., Tan, J. C., Hahn, M. W., \& Besansky, N. J. (2018). Systems genetic analysis of inversion polymorphisms in the malaria mosquito Anopheles gambiae. Proc Natl Acad Sci U S A, 115(30), E7005E7014. doi:10.1073/pnas.1806760115

Cheng, C. D., White, B. J., Kamdem, C., Mockaitis, K., Costantini, C., Hahn, M. W., \& Besansky, N. J. (2012). Ecological Genomics of Anopheles gambiae Along a Latitudinal Cline: A Population-Resequencing Approach. Genetics, 190(4), 1417-1432. doi:10.1534/genetics.111.137794

Chouteau, M., Llaurens, V., Piron-Prunier, F., \& Joron, M. (2017). Polymorphism at a mimicry supergene maintained by opposing frequency-dependent selection pressures. Proc Natl Acad Sci U S A, 114(31), 83258329. doi:10.1073/pnas.1702482114

Clarke, C. A., \& Sheppard, F. R. S. (1972). The genetics of the mimetic butterfly Papilio polytes L. Philosophical 
Transactions of the Royal Society of London. B, Biological Sciences, 263(855), 431-458. doi:10.1098/rstb.1972.0006

Colosimo, P. F., Peichel, C. L., Nereng, K., Blackman, B. K., Shapiro, M. D., Schluter, D., \& Kingsley, D. M. (2004).

Reduction in Threespine Sticklebacks. Plos Biology, 2(5), e109. doi:10.1371/journal.pbio.0020109

Coluzzi, M., Sabatini, A., della Torre, A., Di Deco, M. A., \& Petrarca, V. (2002). A polytene chromosome analysis of the Anopheles gambiae species complex. Science, 298(5597), 1415-1418. doi:10.1126/science.1077769

Coluzzi, M., Sabatini, A., Petrarca, V., \& Di Deco, M. A. (1979). Chromosomal differentiation and adaptation to humn environments in the Anopheles gambiae complex. Royal Society of Tropical Medicine and Hygiene, 73(5), 483-497.

Comeault, Aaron A., Flaxman, Samuel M., Riesch, R., Curran, E., Soria-Carrasco, V., Gompert, Z., . . . Nosil, P. (2015). Selection on a Genetic Polymorphism Counteracts Ecological Speciation in a Stick Insect. Current Biology, 25(15), 1975-1981. doi:10.1016/j.cub.2015.05.058

Corbett-Detig, R. B. (2016). Selection on Inversion Breakpoints Favors Proximity to Pairing Sensitive Sites in Drosophila melanogaster. Genetics, 204(1), 259-265. doi:10.1534/genetics.116.190389

Corbett-Detig, R. B., Cardeno, C., \& Langley, C. H. (2012). Sequence-Based Detection and Breakpoint Assembly of Polymorphic Inversions. Genetics, 192(1), 131-137. doi:10.1534/genetics.112.141622

Corbett-Detig, R. B., \& Hartl, D. L. (2012). Population Genomics of Inversion Polymorphisms in Drosophila 

melanogaster. PLoS Genet, 8(12), e1003056. doi:10.1371/journal.pgen.1003056

Corbett-Detig, R. B., Said, I., Calzetta, M., Genetti, M., McBroome, J., Maurer, N. W., . . Besansky, N. J. (2019). Fine-Mapping Complex Inversion Breakpoints and Investigating Somatic Pairing in the Anopheles gambiae Species Complex Using Proximity-Ligation Sequencing. Genetics, 213(4), 1495-1511. doi:10.1534/genetics.119.302385

Coughlan, J. M., \& Willis, J. H. (2018). Dissecting the role of a large chromosomal inversion in life history divergence throughout the Mimulus guttatus species complex. $\mathrm{Mol}$ Ecol, 28(6), 1343-1357. doi:doi:10.1111/mec.14804 da Silva, V. H., Laine, V. N., Bosse, M., Spurgin, L. G., Derks, M. F. L., van Oers, K., . . Groenen, M. A. M. (2019). The Genomic Complexity of a Large Inversion in Great Tits. Genome Biology and Evolution, 11(7), 18701881. doi:10.1093/gbe/evz106

Darwin, C. (1862). On the Two Forms, or Dimorphic Condition, in the Species of Primula, and on their remarkable Sexual Relations. Journal of the Proceedings of the Linnean Society of London. Botany, 6(22), 77-96. doi:10.1111/j.1095-8312.1862.tb01218.x de Jong, S., Chepelev, I., Janson, E., Strengman, E., van den Berg, L. H., Veldink, J. H., \& Ophoff, R. A. (2012). Common inversion polymorphism at $17 \mathrm{q} 21.31$ affects expression of multiple genes in tissue-specific manner. BMC Genomics, 13(458). doi:10.1186/1471-2164-13458

Dobzhansky, T. G. (1947). Adaptive Changes Induced by Natural Selection in Wild Populations of Drosophila. Evolution, 1(1/2), 1-16. doi:10.2307/2405399 
606

607

608

609

610

611

612

613

614

615

616

617

618

619

620

621

622

623

624

625

626

627

628

629

630

631

632

633

634

635

636

637

638

Dobzhansky, T. G. (1970). Genetics of the Evolutionary Process: Columbia University Press.

Feder, J. L., Gejji, R., Powell, T. H. Q., \& Nosil, P. (2011). ADAPTIVE CHROMOSOMAL DIVERGENCE DRIVEN BY MIXED GEOGRAPHIC MODE OF EVOLUTION. Evolution, 65(8), 2157-2170. doi:10.1111/j.1558-5646.2011.01321.x

Fisher, R. A. (1930). The Genetical Theory of Natural Selection: Oxford.

Ford, E. B. (1965). Genetic Polymorphism. London: Studies Faber \& Faber.

Ford, E. B. (1971). Ecological Genomics (3rd ed.). London: Chapman and Hall LTD.

Fouet, C., Gray, E., Besansky, N. J., \& Costantini, C. (2012). Adaptation to Aridity in the Malaria Mosquito Anopheles gambiae: Chromosomal Inversion Polymorphism and Body Size Influence Resistance to Desiccation. PLoS One, 7(4), e34841.

doi:10.1371/journal.pone.0034841

Gonzalez, D. R., Aramendia, A. C., \& Davison, A. (2019). Recombination within the Cepaea nemoralis supergene is confounded by incomplete penetrance and epistasis. Heredity, 123(2), 153-161. doi:10.1038/s41437-0190190-6

Gray, E. M., Rocca, K. A. C., Costantini, C., \& Besansky, N. J. (2009). Inversion $2 \mathrm{La}$ is associated with enhanced desiccation resistance in Anopheles gambiae. Malaria Journal, 8. doi:10.1186/1475-2875-8-215

Guerrero, R. F., Rousset, F., \& Kirkpatrick, M. (2012). Coalescent patterns for chromosomal inversions in divergent populations. Philosophical Transactions of the Royal Society B-Biological Sciences, 367(1587), 430438. 
639

640

641

642

643

644

645

646

647

648

649

650

651

652

653

654

655

656

657

658

659

660

661

662

663

664

665

666

667

668

669

670

671

Guillén, Y., \& Ruiz, A. (2012). Gene alterations at Drosophila inversion breakpoints provide prima facie evidence for natural selection as an explanation for rapid chromosomal evolution. BMC Genomics, 13(1), 53. doi:10.1186/1471-2164-13-53

Hoffmann, A. A., \& Rieseberg, L. H. (2008). Revisiting the Impact of Inversions in Evolution: From Population Genetic Markers to Drivers of Adaptive Shifts and Speciation? Annual Review of Ecology, Evolution, and Systematics, 39(1), 21-42. doi:10.1146/annurev.ecolsys.39.110707.173532

Hopkins, D. P., Tyukmaeva, V. I., Gompert, Z., Feder, J. L., $\&$ Nosil, P. Functional genomics offers new tests of speciation hypotheses. in press.

Huang, Y.-C., Dang, V. D., Chang, N.-C., \& Wang, J. (2018). Multiple large inversions and breakpoint rewiring of gene expression in the evolution of the fire ant social supergene. Proceedings of the Royal Society B:

Biological Sciences, 285(1878), 20180221.

doi:10.1098/rspb.2018.0221

Huber, B., Whibley, A., Poul, Y. L., Navarro, N., Martin, A., Baxter, S., . . Joron, M. (2015). Conservatism and novelty in the genetic architecture of adaptation in Heliconius butterflies. Heredity, 114(5), 515-524. doi:10.1038/hdy.2015.22

Jay, P., Whibley, A., Frézal, L., Rodríguez de Cara, M. Á., Nowell, R. W., Mallet, J., . . Joron, M. (2018).

Supergene Evolution Triggered by the Introgression of a Chromosomal Inversion. Current Biology, 28(11), 18391845.e1833. doi:10.1016/j.cub.2018.04.072 Jones, F. C., Grabherr, M. G., Chan, Y. F., Russell, P., Mauceli, E., Johnson, J., . . Kingsley, D. M. (2012). The genomic basis of adaptive evolution in threespine 
sticklebacks. Nature, 484, 55-61. doi:10.1038/nature10944

https://www.nature.com/articles/nature10944\#supplementaryinformation

Joron, M., Frezal, L., Jones, R. T., Chamberlain, N. L., Lee, S. F., Haag, C. R., . . . ffrench-Constant, R. H. (2011).

Chromosomal rearrangements maintain a polymorphic supergene controlling butterfly mimicry. Nature, 477(7363), 203-206. doi:10.1038/nature10341

Joron, M., Wynne, I. R., Lamas, G., \& Mallet, J. (1999). Variable selection and the coexistence of multiple mimetic forms of the butterfly Heliconius numata. Evolutionary Ecology, 13(7-8), 721-754. doi:10.1023/A:1010875213123

Kapan, D. D. (2001). Three-butterfly system provides a field test of mullerian mimicry. Nature, 409(6818), 338-340. doi:10.1038/35053066

Kirkpatrick, M. (2010). How and Why Chromosome Inversions Evolve. Plos Biology, 8(9), e1000501. doi:10.1371/journal.pbio.1000501

Kirkpatrick, M., \& Barton, N. (2006). Chromosome Inversions, Local Adaptation and Speciation. Genetics, 173(1), 419-434. doi:10.1534/genetics.105.047985 Kirubakaran, T. G., Grove, H., Kent, M. P., Sandve, S. R., Baranski, M., Nome, T., . . A Andersen, O. (2016). Two adjacent inversions maintain genomic differentiation between migratory and stationary ecotypes of Atlantic cod. Mol Ecol, 25(10), 2130-2143. doi:10.1111/mec.13592

Kraft, K., Geuer, S., Will, Anja J., Chan, Wing L., Paliou, C., Borschiwer, M., . . . Andrey, G. (2015). Deletions, Inversions, Duplications: Engineering of Structural 
Variants using CRISPR/Cas in Mice. Cell Reports, 10(5), 833-839. doi:https://doi.org/10.1016/j.celrep.2015.01.016 Kunte, K., Zhang, W., Tenger-Trolander, A., Palmer, D. H., Martin, A., Reed, R. D., . . Kronforst, M. R. (2014). doublesex is a mimicry supergene. Nature, 507(7491), 229-232. doi:10.1038/nature 13112

Kupper, C., Stocks, M., Risse, J. E., dos Remedios, N., Farrell, L. L., Mcrae, S. B., . . Burke, T. (2016). A supergene determines highly divergent male reproductive morphs in the ruff. Nature Genetics, 48(1), 79-83. doi:10.1038/ng.3443

Lamichhaney, S., Fan, G. Y., Widemo, F., Gunnarsson, U., Thalmann, D. S., Hoeppner, M. P., . . A Andersson, L. (2016). Structural genomic changes underlie alternative reproductive strategies in the ruff (Philomachus pugnax). Nature Genetics, 48(1), 84-88. doi:10.1038/ng.3430 Lee, C. R., Wang, B. S., Mojica, J. P., Mandakova, T., Prasad, K. Y. S. K., Goicoechea, J. L., . . . Mitchell-Olds, T. (2017). Young inversion with multiple linked QTLs under selection in a hybrid zone. Nature Ecology \& Evolution, 1(5). doi:10.1038/s41559-017-0119

Lemopoulos, A., Uusi-Heikkilä, S., Huusko, A., Vasemägi, A., \& Vainikka, A. (2018). Comparison of Migratory and Resident Populations of Brown Trout Reveals Candidate Genes for Migration Tendency. Genome Biology and Evolution, 10(6), 1493-1503. doi:10.1093/gbe/evy102 Li, J., Cocker, J. M., Wright, J., Webster, M. A., McMullan, M., Dyer, S., . . . Gilmartin, P. M. (2016). Genetic architecture and evolution of the $\mathrm{S}$ locus supergene in Primula vulgaris. Nature Plants, 2(12), 16188. doi:10.1038/nplants.2016.188

Ling, A., \& Cordaux, R. (2010). Insertion Sequence Inversions Mediated by Ectopic Recombination between 
Terminal Inverted Repeats. PLoS One, 5(12), e15654. doi:10.1371/journal.pone.0015654 Lowry, D. B., \& Willis, J. H. (2010). A Widespread Chromosomal Inversion Polymorphism Contributes to a Major Life-History Transition, Local Adaptation, and Reproductive Isolation. Plos Biology, 8(9), e1000500. Mallet, J., \& Barton, N. H. (1989). Strong Natural-Selection in a Warning-Color Hybrid Zone. Evolution, 43(2), 421431. doi:Doi 10.2307/2409217

Mather, K. (1950). The Genetical Architecture of Heterostyly in Primula sinensis. Evolution, 4(4), 340-352. doi: $10.2307 / 2405601$

Mather, K. (1955). Polymorphism as an Outcome of Disruptive Selection. Evolution, 9(1), 52-61. doi:10.2307/2405357

Matzkin, L. M., Merritt, T. J. S., Zhu, C.-T., \& Eanes, W. F. (2005). The structure and population genetics of the breakpoints associated with the cosmopolitan chromosomal inversion In(3R)Payne in Drosophila melanogaster. Genetics, 170(3), 1143-1152. doi:10.1534/genetics.104.038810

McBroome, J., Liang, D., \& Corbett-Detig, R. (2020). Finescale position effects shape the distribution of inversion breakpoints in Drosophila melanogaster. Genome Biology and Evolution. doi:10.1093/gbe/evaa103 Merrill, R. M., Wallbank, R. W. R., Bull, V., Salazar, P. C. A., Mallet, J., Stevens, M., \& Jiggins, C. D. (2012). Disruptive ecological selection on a mating cue. Proceedings of the Royal Society B-Biological Sciences, 279(1749), 4907-4913. doi:10.1098/rspb.2012.1968 Navarro, A., \& Barton, N. H. (2003). Chromosomal Speciation and Molecular Divergence--Accelerated 
Evolution in Rearranged Chromosomes. Science, 300(5617), 321-324. doi:10.1126/science. 1080600 Nichols, K. M., Edo, A. F., Wheeler, P. A., \& Thorgaard, G. H. (2008). The genetic basis of smoltification-related traits in Oncorhynchus mykiss. Genetics, 179(3), 15591575. doi:10.1534/genetics.107.084251

Nishikawa, H., Iijima, T., Kajitani, R., Yamaguchi, J., Ando, T., Suzuki, Y., . . . Fujiwara, H. (2015). A genetic mechanism for female-limited Batesian mimicry in Papilio butterfly. Nature Genetics, 47(4), 405-409. doi:10.1038/ng.3241

Nosil, P., Villoutreix, R., de Carvalho, C. F., Farkas, T. E., Soria-Carrasco, V., Feder, J. L., . . Gompert, Z. (2018). Natural selection and the predictability of evolution in Timema stick insects. Science, 359(6377), 765-770. doi:10.1126/science.aap9125

O'Malley, K. G., Sakamoto, T., Danzmann, R. G., \& Ferguson, M. M. (2003). Quantitative Trait Loci for Spawning Date and Body Weight in Rainbow Trout: Testing for Conserved Effects Across Ancestrally Duplicated Chromosomes. Journal of Heredity, 94(4), 273-284. doi:10.1093/jhered/esg067

Pearse, D. E., Miller, M. R., Abadia-Cardoso, A., \& Garza, J. C. (2014). Rapid parallel evolution of standing variation in a single, complex, genomic region is associated with life history in steelhead/rainbow trout. Proceedings of the Royal Society B-Biological Sciences, 281(1783). doi:10.1098/rspb.2014.0012

Pevzner, P., \& Tesler, G. (2003). Human and mouse genomic sequences reveal extensive breakpoint reuse in mammalian evolution. Proceedings of the National Academy of Sciences, 100(13), 7672. doi:10.1073/pnas.1330369100 
802

803

804

805

806

807

808

809

810

811

812

813

814

815

816

817

818

819

820

821

822

823

824

825

826

827

828

829

830

831

832

833

834

Piper, J., \& Charlesworth, B. (2008). The evolution of distyly in Primula vulgaris. Biological Journal of the Linnean Society, 29(2), 123-137. doi:10.1111/j.10958312.1986.tb01827.x

Puig, M., Casillas, S., Villatoro, S., \& Caceres, M. (2015). Human inversions and their functional consequences. Briefings in Functional Genomics, 14(5), 369-379. doi:10.1093/bfgp/elv020

Ranz, J. M., Maurin, D., Chan, Y. S., von Grotthuss, M., Hillier, L. W., Roote, J., . . Bergman, C. M. (2007). Principles of Genome Evolution in the Drosophila melanogaster Species Group. Plos Biology, 5(6), e152. doi:10.1371/journal.pbio.0050152

Robison, B. D., Wheeler, P. A., Sundin, K., Sikka, P., \& Thorgaard, G. H. (2001). Composite Interval Mapping Reveals a Major Locus Influencing Embryonic Development Rate in Rainbow Trout (Oncorhynchus mykiss). Journal of Heredity, 92(1), 16-22.

doi:10.1093/jhered/92.1.16

Rocca, K. A. C., Gray, E. M., Costantini, C., \& Besansky, N. J. (2009). 2La chromosomal inversion enhances thermal tolerance of Anopheles gambiae larvae. Malaria Journal, 8. doi:10.1186/1475-2875-8-147

Ross, K. G., \& Keller, L. (1995). Ecology and Evolution of Social-Organization - Insights from Fire Ants and Other Highly Eusocial Insects. Annual Review of Ecology and Systematics, 26, 631-656. doi:DOI 10.1146/annurev.es.26.110195.003215

Sandoval, C. P. (1994). Differential visual predation on morphs of Timema cristinae (Phasmatodeae:Timemidae) and its consequences for host range. Biological Journal of the Linnean Society, 52(4), 341-356. doi:doi:10.1111/j.1095-8312.1994.tb00996.x 
Sandoval, C. P., \& Nosil, P. (2005). Counteracting selective regimes and host preference evolution in ecotypes of two species of walking-sticks. Evolution, 59(11), 2405-2413. Sharakhov, I. V., White, B. J., Sharakhova, M. V., Kayondo, J., Lobo, N. F., Santolamazza, F., . . Besansky, N. J. (2006). Breakpoint structure reveals the unique origin of an interspecific chromosomal inversion $2 \mathrm{La}$ in the Anopheles gambiae complex. Proceedings of the National Academy of Sciences, 103(16), 6258-6262. doi:10.1073/pnas.0509683103

Sinclair-Waters, M., Bradbury, I. R., Morris, C. J., Lien, S., Kent, M. P., \& Bentzen, P. (2018). Ancient chromosomal rearrangement associated with local adaptation of a postglacially colonized population of Atlantic Cod in the northwest Atlantic. Mol Ecol, 27(2), 339-351. doi:10.1111/mec. 14442

Stefansson, H., Helgason, A., Thorleifsson, G., Steinthorsdottir, V., Masson, G., Barnard, J., . . . Stefansson, K. (2005). A common inversion under selection in Europeans. Nature Genetics, 37(2), 129-137. doi:10.1038/ng1508

Stewart, N. B., \& Rogers, R. L. (2019). Chromosomal rearrangements as a source of new gene formation in Drosophila yakuba. PLoS Genet, 15(9), e1008314. doi:10.1371/journal.pgen.1008314

Sturtevant, A. H. (1921). A Case of Rearrangement of Genes in Drosophila. Proc Natl Acad Sci U S A, 7(8), 235-237. doi:10.1073/pnas.7.8.235

Thomas, J. W., Cáceres, M., Lowman, J. J., Morehouse, C. B., Short, M. E., Baldwin, E. L., . . Martin, C. L. (2008). The Chromosomal Polymorphism Linked to Variation in Social Behavior in the White-Throated Sparrow (Zonotrichia albicollis) Is a Complex Rearrangement and 
Suppressor of Recombination. Genetics, 179(3), 14551468. doi:10.1534/genetics.108.088229

Thorneycroft, H. B. (1966). Chromosomal Polymorphism in the White-Throated Sparrow, Zonotrichia albicollis (Gmelin). Science, 154(3756), 1571-1572.

Throneycroft, H. B. (1975). A Cytogenetic Study of the White-Throated Sparrow, Zonotrichia albicollis (Gmelin). Evolution, 29(4), 611-621. doi: $10.2307 / 2407072$

Tuttle, E. M., Bergland, A. O., Korody, M. L., Brewer, M. S., Newhouse, D. J., Minx, P., . . Balakrishnan, C. N. (2016). Divergence and Functional Degradation of a Sex Chromosome-like Supergene. Current Biology, 26(3), 344-350.

Van Belleghem, S. M., Rastas, P., Papanicolaou, A., Martin, S. H., Arias, C. F., Supple, M. A., . . Papa, R. (2017). Complex modular architecture around a simple toolkit of wing pattern genes. Nature Ecology \& Evolution, 1, 0052. doi:10.1038/s41559-016-0052

http://www.nature.com/articles/s41559-0160052\#supplementary-information

Villoutreix, R., de Carvalho, C. F., Soria-Carrasco, V., Lindtke, D., De-la-Mora, M., Muschick, M., . . . Nosil, P. (2020). Large-scale mutation in the evolution of a gene complex for cryptic coloration. Science, 369(6502), 460466. doi:10.1126/science.aaz4351

Wang, J., Wurm, Y., Nipitwattanaphon, M., Riba-Grognuz, O., Huang, Y. C., Shoemaker, D., \& Keller, L. (2013). A Y-like social chromosome causes alternative colony organization in fire ants. Nature, 493(7434), 664-668. doi:10.1038/nature11832

Yan, Z., Martin, S. H., Gotzek, D., Arsenault, S. V., Duchen, P., Helleu, Q., . . Keller, L. (2020). Evolution of a 

supergene that regulates a trans-species social polymorphism. Nature Ecology \& Evolution, 4, 240-249.

903 